\title{
Development of the INEEL Site Wide Vadose Zone Roadmap
}

September 2001

Idaho National Engineering and Environmental Laboratory Bechtel BWXT Idaho, LLC 


\section{Development of the INEEL Site Wide Vadose Zone Roadmap}

September 2001

Idaho National Engineering and Environmental Laboratory Idaho Falls, Idaho 83415

Prepared for the U.S. Department of Energy Under DOE Idaho Operations Office Contract DE-AC07-99ID13727 


\section{DEVELOPMENT OF THE INEEL SITE-WIDE VADOSE ZONE ROAD-MAP}

\section{INTRODUCTION}

The INEEL Vadose Zone Roadmap (the Roadmap) was developed to identify inadequacies in current knowledge, to assist in contaminant management capabilities relative to the INEEL vadose zone, and to ensure that ongoing and planned Science and Technology (S\&T) developments will meet the risk management challenges facing the INEEL in coming years. The primary objective of the Roadmap is to determine the S\&T needs that will facilitate monitoring, characterization, prediction, and assessment activities necessary to support INEEL risk management decisions and to ensure that long-term stewardship of contaminated sites at the INEEL is achieved. The mission of the Roadmap is to insure that the long-term S\&T strategy is aligned with site programs, that it takes advantage of progress made to date, and that it can assist in meeting the milestones and budgets of operations.

\section{BACKGROUND}

Managing contaminated sites involves characterization of the affected areas, determination of contaminant release history and assessment of current and future risk. Each of these steps introduces a measure of uncertainty that is not fully quantifiable. The process knowledge and data obtained during the assessment stage is used to develop a Record of Decision (ROD) that documents the remedial actions required to achieve acceptable risk. Possible remedial actions include removing or destroying selected contaminants, stabilizing contaminants in place, or relocating contaminated material to locations off of the INEEL. Following the development of the ROD, the Remedial Decision/Remedial Action (RD/RA) phase implements the mitigating actions leading to an end state of acceptable risk. The final management stage involves monitoring the site to ensure that the remedial goals have been met and to allow early detection of hazards outside of the established risk. After proven successful remediation, the maintenance of acceptable risk is integrated with other site management functions as a component of DOE's long-term stewardship program.

At the INEEL, contaminated sites include those affected by historical releases (managed through the CERCLA process), sites corresponding to currently operational facilities (managed through the RCRA program), and buildings that are under the Decontamination and Decommissioning (D\&D) programs. At the INEEL, CERCLA sites are grouped by waste area (Waste Area Groups, or WAGs), and typically correspond to facility boundaries.

Table 2-1: INEEL Facility Name and Corresponding Waste Area Group (WAG) Designation

\begin{tabular}{|l|c|}
\hline \multicolumn{1}{|c|}{ INEEL Facility Name } & Waste Area Group (WAG) Designation \\
\hline Test Area North (TAN) & WAG - 1 \\
\hline Teat Reactor Area (TRA) & WAG - 2 \\
\hline Idaho Nuclear Technology and Engineering Center (INTEC) & WAG -3 \\
\hline Central Facilities Area & WAG -4 \\
\hline Power Burst Facility and Auxiliary Reactor Area & WAG - 5 \\
\hline Experimental Breeder Reactor No. 1 & WAG - 6 \\
\hline Radioactive Waste Management Complex & WAG -7 \\
\hline Miscellaneous Sites and Sitewide Area & WAG - 10 \\
\hline
\end{tabular}

Within each WAG, several release sites exist, and are referred to as Operable Units (OUs). Most of the RODs for the CERCLA sites are in place, with only 3 of 22 RODS, including those for WAG 7 (OU 7-13/14), WAG 3 (OU3-14), and WAG 10 unsigned. Of these remaining, the operable unit corresponding to Pit 9 (OU 7-10) is currently proceeding under an Interim Action ROD, and OU-7-13/14 is the entire Subsurface Disposal Area. Operable unit OU 3-14 corresponds to the Tank Farm at the INTEC 
facility, and is currently in the Remedial Investigation/Feasibility Study stage (pre-ROD), and contaminated sites falling outside facility boundaries and within the general Snake River Plain Aquifer are included in the two comprehensive WAG 10 RODs, one for soils and one for groundwater. Although remedial actions have been selected for the OUs operating under existing RODs, these RODs allow for adapting new remedial responses given adequate technical justification.

Non-CERCLA analysis, yet to be completed, include analyses of RCRA closure sites that will affect the majority of radionuclides at the INEEL. Additional analyses of potential hazards also remain for facilities that fall under the Decontamination, Decommissioning, and Dismantlement (D\&D\&D) program and for planned facilities, such as Idaho CERCLA Disposal Facility. Ultimately, stewardship of the INEEL will only be as effective as the understanding of cumulative risk from all sources allows. A comprehensive analysis that considers cumulative impacts from all contaminant management decisions may result in a re-evaluation of some decisions already in place.

Facilitating scientific advances that result in better remedial options, that reduce the inherent uncertainty, and that ultimately reduce the public health risk is one of the goals of this Roadmap. Advances in characterization, monitoring, prediction, assessment, and containment technologies are identified in the Roadmap and can impact regulatory decisions that affect ongoing and proposed remedial actions. These impacts can be incorporated into ongoing remedial actions by exercising the ROD amendment option provided by the CERCLA (42 USC $\$ 9601$ et seq.) guidance. Under this guidance, new technology can be used at anytime to improve the schedule or cost during the remediation of a contaminated area in addition to allowing its use following the 5-year review of each ROD. For sites currently in the RI/FS or ROD process, information garnered through $\mathrm{S} \& \mathrm{~T}$ advances can be used to support the decision and remedial action selection processes.

\section{ROADMAP CONTENTS}

The draft INEEL Vadose Zone Roadmap as contained in "Uncertain Predictions of Contaminant Behavior at INEEL: A Roadmap for Addressing Current Limitations through Vadose Zone Studies." It presents the S\&T investments required to enhance our understanding of transport and transformation processes occurring in the vadose zone and groundwater environments, which will lead to increased confidence in the decisions affecting risk management decisions. Activities identified in the Roadmap document and future Science Plans must support the ability to predict risks associated with contaminants that will be left in place after INEEL operations are complete and must result in monitoring and containment of those contaminants as long as they pose a potential risk.

The Roadmap begins by clarifying the primary remaining decision points, it then presents the basis for making environmental management decisions, and follows with a review of the key sources of uncertainty. Additionally, it sets goals for conducting research, and presents the basis for prioritizing specific research directions. Each of these components is reviewed briefly below. The primary drivers are operations, regulations, decisions, budget, planning, and end state options.

Several key remaining cleanup decisions at the INEEL have been identified through the roadmapping process and are listed in Table 3-1. From this table, it is apparent that the decision time line spans roughly 50 years. During this time, advances can be made in characterization, monitoring, prediction, and waste stabilization that can impact regulatory decisions and remedial actions. Scientific and technological advancements can be incorporated into ongoing remedial actions by exercising the ROD amendment option provided by CERCLA (42 USC $\$ 9601$ et seq.) guidance, which states that new technology can be used anytime during remediation of a waste site in addition to allowing its use following the 5-year ROD review. Determining areas where advances must be made requires and understanding of the decision basis, which varies across the INEEL. 
Table 3.1: Key Remaining Decision Points

\begin{tabular}{|c|c|c|}
\hline $\begin{array}{c}\text { Planning } \\
\text { Date }\end{array}$ & Operation, Regulation, or Decision Point & $\begin{array}{c}\text { Technical Issues in } \\
\text { Reaching an End State } \\
\end{array}$ \\
\hline 2003 & WAG 7ROD & Transport uncertainty \\
\hline 2003 & WAG 1-07 Plume remediation completion & Adequate monitoring capabilities \\
\hline$\sim 2005$ & OU 13-14 ROD (INTEC-Tank Farm) & Uncertainty in risk predictions \\
\hline$\sim 2010$ & SDA Closure & Uncertainty in risk predictions \\
\hline$\sim 2020$ & $\begin{array}{l}\text { Advanced Mixed Waste Treatment Facility } \\
\text { (AMWTF) Closure }\end{array}$ & $\begin{array}{l}\text { Adequate characterization and monitoring, } \\
\text { and risk prediction }\end{array}$ \\
\hline 2032 & $\begin{array}{l}\text { INEEL CERCLA Disposal Facility (ICDF) } \\
\text { Closure }\end{array}$ & $\begin{array}{l}\text { Uncertainty in design, risk prediction, } \\
\text { monitoring, characterization }\end{array}$ \\
\hline 2050 & INEEL Closure & $\begin{array}{l}\text { Uncertainty in design, risk prediction, } \\
\text { monitoring, characterization }\end{array}$ \\
\hline \multirow[t]{5}{*}{$\overline{\mathrm{D} \& \mathrm{D}}$} & CPP-603 & \multirow{5}{*}{$\begin{array}{l}\text { Adequate } \\
\text { capability }\end{array}$} \\
\hline & TAN-607 & \\
\hline & TRA (ETR \& MTR) & \\
\hline & PBF & \\
\hline & ATR/canals & \\
\hline $\begin{array}{l}\text { INEEL } \\
\text { HLW }\end{array}$ & INTEC HLW Facility Dispensation & $\begin{array}{l}\text { Dispensation of Tank Contents, Facility } \\
\text { Piping, and Calcine }\end{array}$ \\
\hline
\end{tabular}

\subsection{Decision basis and sources of uncertainty}

At the INEEL, environmental management decisions are based on current and potential public health impact. There are essentially two measures of health impact: the first is an measure of risk, and the second is a maximum concentration level (MCL). Risk via ingestion, as defined by the EPA, is expressed by:

$$
\text { risk }=\text { Exposure Factor }{ }^{*} \text { Toxicity* Contaminant Concentration }
$$

and is composed of several elements including exposure factors and scenarios, contaminant toxicity, and contaminant concentration. The first two of these are dictated by the regulatory agencies and long term use of the land, while the third term provides the focus of the proposed research. The exposure factor is determined by land use scenarios, which includes residential, agricultural, and industrial use scenarios for land and water, and are determined by the EPA. Chemical and radiological toxicity is contaminant specific and is also set by the EPA. The contaminant concentrations of interest to the roadmapping study, are the concentrations of contaminants in subsurface waters that can be used for domestic, agricultural, and industrial purposes. The waters of interest are those that occur in harvestable quantities, and are found in the Snake River Aquifer (SRPA), and those occurring in pumpable levels in the vadose zone.

To evaluate risk stemming from the use of subsurface water, contaminant concentrations in saturated regions (perched water and within the aquifer) are used as opposed to soil pore-water concentrations. These concentrations are spatially and temporally variable, and depend on the release history of contaminants and on the travel path through the vadose zone. To evaluate current risk, contaminant concentrations are measured at a limited number of locations, and assumptions are made about their spatial continuity and distribution. To evaluate future risk, contaminant concentrations must be predicted over time frames of interest to regulators and to the public. The prediction interval depends on specific contaminants and on the management decision. Time frames can span several months for interim actions or can span 10,000 years for permanent storage of long-lived radionuclides. Environmental management 
decisions made at INEEL have traditionally relied on predicting future contaminant concentrations with models starting with release history and matching current measurements. Because of our lack of understanding of subsurface phenomena and our inability to translate point measurements over spatial scales, there are large uncertainties associated with these predictions of future contaminant behavior.

Information about hydrogeochemical properties or state variables (i.e., pressure, moisture content, and concentration) in highly heterogeneous porous media, such as the fractured basalt-sediment materials underlying the INEEL, are always uncertain to some degree. We have a limited ability to quantify heterogeneous physical, biogeochemical, and hydraulic properties and their nonlinear relationships to state variables. The data are used in computer models, generally employing simplified algorithms, to describe transport and transformations to predict future contaminant behavior. Uncertainty imbedded in the estimates of parameters, state variables, infiltration rates, and contaminant sources are then propagated and compounded in the modeling process, resulting is a large degree of uncertainty in predictions of contaminant concentrations.

In systems at risk, the EPA typically sets drinking water contamination goals to fall within the 1E-6 to $1 \mathrm{E}-4$ risk range. One interpretation of this range is that risk must be predicted within a factor of 100 to make environmental decisions regarding remedial actions. The range also suggests a need to quantify the uncertainty of all components used in modeling contaminant fate and transport, and to understand how to manage the distribution of uncertainty between data sets and functional relationships. To minimize erroneous environmental management decisions, uncertainties in predictions of future contaminant behavior need to be understood and quantified.

The relative importance of parameters and processes in determining the uncertainty is currently unknown. Additionally, parameters and state variables are not typically measured with methodology allowing assessment of uncertainty. The Roadmap places these sources into four primary categories:

- Theory uncertainty addresses our ability to approximate the real world with a conceptual model. Models used as the basis for decision making need to capture relevant processes (e.g., flow, transport, and transformation) at the level of detail necessary to describe the governing phenomena at relevant temporal and spatial scales. The individual processes included in the models determine which parameters and state variables must be quantified. In addition, each process model determines the required characterization methods and data density.

- Parameter uncertainty is introduced in heterogeneous environments and must be quantified in context of the process model used to analyze the information. Interpretation of measured parameters over varying distances (i.e., spatial scales) is one of the key challenges facing subsurface environmental predictions, and the issue is probably best known as the scaling phenomena. An additional source of parameter uncertainty is introduced through the interpretation of measurements of different parameters made over disparate volumes. An example is provided by measurements of water potential obtained using a limited volume sampling device (e.g., an advanced tensiometer) and measurements of water content obtained using volume averaged geophysical techniques: the result doesn't necessarily describe accurately the relationships between water potential and water content, which is needed to predict unsaturated water flow.

Important issues relevant to spatial scaling encountered during predicting transport and transformation at the INEEL include determining how to a) incorporate microscale biogeochemical processes into field scale prediction, b) how to extend observations of flow through single fractures to predict field scale transport, and c) how to interpret measurements of water content and water potential over volumes representative of field scale transport. At the NNEEL, the parameter space includes biologic, geologic, geochemical, and hydrologic variables for the fractured basalt and the interlayered sediments comprising the Snake River Plain system.

- Interpretation uncertainty is introduced through use of indirect estimates of state variables, and by analyzing data in the context of incorrect process models. An example of the first includes using electrical geophysical signals to infer moisture content in heterogeneous media. An example of the second includes inferring hydraulic conductivity in layered sediment and 
fractured basalt media using a Theis curve approximation developed for radially symmetric flow in confined homogeneous aquifers. In each of these examples, it is not clear what is being measured or how to interpret the obtained values, increasing the overall model uncertainty.

- Source estimate uncertainty is introduced when reconstructing historical release inventory and duration when the discharges are poorly (if at all) documented. The problem is compounded when the end state of the facility is yet to be determined and when sampling facility contents is impossible. The potential for exposing personnel to hazardous conditions often precludes our ability to investigate contaminated sites, operational facilities, or facilities with unknown dangers.

The S\&T research program will be designed to address each of these areas of uncertainty.

\section{PRIORITIES AND OBJECTIVES OF SCIENCE AND TECHNOLOGY RESEARCH}

Priorities for science and technology research will be determined on the potential to quantify and reduce the uncertainty in risk predictions. Across the INEEL, the contaminant release history, contaminant inventory, subsurface environment, and surface driving forces vary. Among the individual OUs, the decision time frames have been determined. The needs of individual remedial actions across the sites of ER, EM, SNF, HLW, and stewardship projects are quite diverse. Each of these factors will impact the relative priority given to individual scientific and technological advances. The objectives of science and technology developments will be to achieve acceptable levels of confidence in environmental management decisions. This requires quantification and reduction in risk prediction uncertainty. The short-term agenda and anticipated activities are listed below:

- Prioritization of existing contaminated sites, future closures, and other environmental management decisions by risk through time. The diversity across the sites, specific regulatory time frames and requirements will necessitate that the sites be prioritized. Prioritization will allow focusing scientific advances, and will maximize the integration between end-users and the scientific community. Thus, the first step in completing the technical plan will be the review of historical and future decision points and the ranking of sites by risk over time. This is expected to occur during FY 01- 02.

- Workshops to bring environmental problem holders, regulators, and practitioners together. As stated above, it is imperative that the end-user communities are involved from the beginning to successfully integrate the scientific advances into management processes. The purpose of these workshops will be to initiate open communication, to complete the assessment of analysis limitations and to ensure that the proposed path forward is acceptable to all involved. This is expected to occur during FY 2002 - throughout the duration of the project.

- Development of research agenda. In order for the proposed S\&T approach to succeed, the scientific advances must be mutually supportive. Given the overall complexity of vadose zone transport at the INEEL, the research agenda will initially focus on the development and testing of instrumentation, sensors, data handling capabilities, and data analyses required to support laboratory-scale investigations. These investigations will include micro-scale determination of geochemical reactions on native materials, and meso-scale experiments to elucidate flow and transport processes through representative INEEL media. Concurrent numerical simulators will be developed and tested to facilitate the use of new information, develop and test research hypotheses, and optimize the simulation process. These controlled experiments and technology development will occur through out the next five years.

- Field-scale implementation of scientific advances will be required to address the contaminant management issues facing the INEEL. As research tools become available, they will be migrated to the field. The initial developments will occur, as sensors are developed and as lithostratigraphic and chemical characterization technologies become available. As these tools collect 
sufficient data, field-scale experiments will be performed to elucidate flow and transport conditions and to test the hypotheses developed at the meso-scale and at field conditions. This is expected to occur throughout the next 10 years, with most of the field-scale manipulative experiments occurring during the second 5 years.

\section{ROADMAP DEVELOPMENT}

In main, the development of this S\&T roadmap followed the guidance set forth in:

- Introduction to Technology Roadmapping: The Semiconductor Industry Association's Technology Roadmapping Process, 1997, Sandia National Laboratory (SNL) Report SAND97-0666.

- Fundamentals of Technology Roadmaping, 1998, SNL Business Development Department.

- Technology Roadmapping: an Overview. Presentation by McNeil Technologies for the Complex-Wide Vadose Zone Roadmapping Project, 1999.

- Applying Technology Roadmapping in Environmental Management (draft), 2000, DOE EM-50.

Additionally, similarities to the INEEL S\&T requirements were found at Hanford, where the Hanford VZ/GW Integration Program has developed an S\&T roadmap to address their environmental contaminant problems. Given the technical and regulatory similarities, the National Academy of Sciences reviewed Hanford roadmap was adapted as the template for this Roadmap.

Steps involved in the roadmapping process included:

- Determining the level of knowledge concerning contaminant inventories, subsurface properties and processes, and predictive capabilities required to address contaminant issues at the INEEL. The state of knowledge, acknowledged deficiencies, and recommendations for addressing the deficiencies are captured in the "Deficiencies in Vadose Zone Understanding at the ldaho National Engineering and Environmental Laboratory" (INEEL/EXT-99-00984) report. We note that the deficiencies document was developed primarily from the perspective of quantifying concentrations resulting from transport and transformation of contaminants beneath the INEEL. To affect operational decisions, aspects of risk and uncertainty must also be assessed.

- Development of the document, "Uncertain Predictions of Contaminant Behavior at INEEL: A Roadmap for Addressing Current Limitations Through Vadose Zone Studies"

INEEL/EXT-2001-00552. This document was developed to illustrate where uncertainties arise in predictions of contaminant behavior in the unsaturated zone between the land surface and the underlying Snake River Plain Aquifer (SRPA) at the INEEL, and to underscore the scientific advances required to quantify and reduce that uncertainty. Although much has been accomplished and learned through the analysis of contaminated sites at the INEEL, significant gaps remain. In an effort to close the gaps, the report details limitations in analysis conducted thus far, and recommends specific actions to address the limitations. Currently, the vadose zone experts at the INEEL cannot with confidence predict the movement of water and contaminants through the heterogeneous fractured basalts and sediments comprising the vadose zone, and this results in highly uncertain environmental management decisions.

- Arrange for an independent external peer review of the roadmapping program.

- Insertion of technology developments and expected scientific advances into the major programmatic milestones associated with the site programs. In addition to meshing the developments identified in the roadmap with programmatic needs, the science plans will be integrated with the Subsurface Science Initiative (SSI) activities. The SSI will conduct an internal peer review and several of the science plan tasks will be incorporated into that program. Full 
integration with programmatic baselines and SSI involvement is expected to be complete in 2001. At this point, an external peer review committee will review this Roadmap.

\section{DISCUSSION OF THE INDEPENDENT PEER REVIEW OF THE INEEL VZ ROADMAP}

Based on a request from the Office of Science and Technology (OST), Office of Environmental Management, U.S. Department of Energy (DOE), a Review Panel (RP) was established by the American Society of Mechanical Engineers (ASME) and the Institute for Regulatory Science (RSI) to peer review the "Science \& Technology Roadmaps for the Vadose Zone at the Idaho National Engineering and Environmental Laboratory" (INEEL) project. The RP received the two documents discussed previously in Section 5 provided by the Project. The Technical Secretary of the RP prepared a project summary and the nine review criteria. These were subsequently approved by the project team and distributed to the RP. On August 20-24, 2001, the RP met in Idaho Falls, ID. This meeting consisted of two parts. At the beginning of part one, which consisted of a workshop, the RP was introduced to the ASME peer review process and the DOE's desire for a non-conflicted and independent peer review. Subsequently, the RP was presented information by the project team and others. In addition, various stakeholders were given the opportunity not only to ask questions from the presenters, but also to make statements addressing specific review criteria. The second part of the meeting consisted of an executive session during which the RP prepared its findings and recommendations of the "Report of the Review Panel".

The report presents findings with respect to the 9 review criteria, additional RP findings, and recommendations for the path forward for the program. The RP recommendations for the project are as follows:

1. The Project Team-in concert with the stakeholders (including regulators)-should develop a project plan and related flowcharts which identifies the steps needed to accomplish the project objectives for the roadmap. The project plan should include: 1) a clear statement of the vision for the roadmapping project; 2) a clear set of objectives that includes risk assessment and remediation strategies; 3) applicable current technologies and future technology needs; 4) specific products that will result from the roadmapping process; 5) metrics of success; and 6) the S\&T plan.

2. The Project Team should develop a comprehensive management plan. This management plan should address such items as methods to ensure effective communication among all parties; project management and technical reviews; and independent peer reviews.

3. The Project Team should document how the INEEL vadose roadmap fits into current and future INEEL operations and site-wide environmental restoration-including long-term stewardship.

4. Once recommendations 1-3 have been addressed, the Project Team should develop its path forward.

5. With respect to plans for reducing uncertainties, the Project Team should develop a mechanismincluding the use of expert elicitation and probabilistic approaches-to identify those uncertainty reduction efforts that would have the most significant impacts on achieving the project objectives.

6. The Project Team should use the numerical and conceptual models in the design of experiments and data collection. Furthermore, to refine these models and develop confidence, the Project Team should use these models to predict and document expected results-together with their confidence ranges-prior to data collection.

7. The Project Team should conduct a thorough review of all available literature related to other DOE sites; particularly Yucca Mountain, the Nevada Test Site, and other pertinent documents that are relevant to the issues at INEEL.

8. The Project Team should: 1) link the text presented in "Uncertain Predictions of Contaminant 
Behavior at INEEL: A Roadmap for Addressing Current Limitations Through Vadose Zone Studies" (3) with the Vadose Zone Science \& Technology Roadmap figure; explain the elements included in the source term; the surface water; the vadose zone; and the groundwater, and identify all subheadings; 2) distinguish between the hydrologic and radiologic source terms using standard industry definitions; 3 ) address the role of climate change as it may affect surface water (i.e., episodic infiltration and surface flooding) and potential changes in the water table elevation that may impact contaminant travel time; 4) explain why risk assessment and remediation are not included in the INEEL "Vadose Zone Science \& Technology Roadmap" (3) while they are part of the Hanford Science \& Technology Program (9).

9. The Project Team should develop a regular meeting schedule with stakeholders (including regulators) to incorporate their concerns into the roadmapping process.

10. The Project Team should encourage and facilitate the publication of articles in peer-reviewed journals, and the presentation of these research results at national scientific meetings.

11. The Project Team should clearly link the design of the mesoscale testing facilities and experiments to uncertainty reduction needs. In addition, the Project Team should determine the contribution of the mesoscale testing facilities to the path forward and define what additional components are needed.

12. The pace of this roadmapping project should be accelerated so that the results of the science plan can be incorporated into the environmental restoration decisions as early as possible.

\section{MILESTONES FOR THE INEEL SCIENCE AND TECHNOLOGY RESEARCH PROGRAM}

The following scope and milestones have been developed as a long-term INEEL strategy for management of ecological, economic, social, and health risks associated with contaminant transport in the vadose zone. This scope has been developed to move the INEEL VZ Roadmapping program forward based on the recommendations presented by the ASME/RSI RP.

Scope to Be Performed (FY 2002):

- Develop a Program Execution Plan

- Conduct meetings with INEEL Operations and R\&D personnel to rank environmental decisions by risk through time (rank INEEL sites by risk)

- Stakeholder workshop to discuss the roadmap and the ranking of INEEL sites by risk

- Develop a research agenda for uncertainty management

- Meet with operations to prioritize R\&D with operations needs against site rankings

- Develop science plans for prioritized R\&D activities

- Stakeholder workshop to discuss the science plans/path forward

- Update the roadmap for S\&T insertion points

Scope to Be Performed (FY 2003):

- Begin development of science plan activities related to implementation. 


\section{Scope to Be Performed (FY 2004):}

- Implementation 


\section{Attachment A - Roadmap Wall Chart}

The draft INEEL Vadose Zone Roadmap wall chart is a consolidated portrayal of INEEL cleanup activities and research and development activities related to the vadose zone. The left side of the chart depicts major milestones for cleanup and waste management programs across the site. Interdependencies between programs are also indicated.

The right side of the chart provides details on R\&D planning, both current and proposed. Again, interdependencies are depicted, as well as insertion points into major operations activities. Specific R\&D activities are portrayed on the wall chart via numbered circles (current) and ovals (proposed). These activities are summarized in Table A-1, "INEEL ER R\&D Activities Related to the Vadose Zone.

Table A-1 provides the details on the proposed Environmental Restoration activities related to the vadose zone. This table corresponds to the right hand column of the Vadose Zone Science \& Technology Roadmap wall chart. The table provides the application of the research, the research area, title of the R\&D activity, a brief description of the activity, the wag and operable unit that the research targets, and a desired delivery date. 


\section{Table A-1 - INEEL ER R\&D Activities Related to the Vadose Zone}

\begin{tabular}{|c|c|c|c|c|c|c|}
\hline $\begin{array}{l}\text { ID } \\
\text { No. }\end{array}$ & Application & $\begin{array}{l}\text { Research } \\
\text { Area }\end{array}$ & Title & Description & $\begin{array}{l}\text { Product } \\
\text { Provided } \\
\text { To }\end{array}$ & $\begin{array}{l}\text { Desired } \\
\text { Delivery } \\
\text { Date }\end{array}$ \\
\hline 25 & Remediation & Inventory & $\begin{array}{l}\text { Demonstration of } \\
\text { Polymer Coating } \\
\text { on soil }\end{array}$ & $\begin{array}{l}\text { This project will determine key } \\
\text { fundamental parameters that lead } \\
\text { to development of membranes } \\
\text { for the separation of hazardous } \\
\text { and radioactive DOE legacy } \\
\text { wastes (parameters such as } \\
\text { physical properties of separation } \\
\text { media, and inter-and intra- } \\
\text { molecular interactions involved } \\
\text { in transport/retention } \\
\text { mechanisms). }\end{array}$ & OU 3-13 & $01 / 2000$ \\
\hline 27 & $\begin{array}{l}\text { Long Term } \\
\text { Monitoring }\end{array}$ & Inventory & $\begin{array}{l}\text { Biotransformation } \\
\text { of Mixed } \\
\text { Inorganic Ions }\end{array}$ & $\begin{array}{l}\text { This study is to increase our } \\
\text { understanding of geochemical } \\
\text { environments and their roles in } \\
\text { fate and transport of } \\
\text { contaminants by evaluating } \\
\text { procedures for modeling } \\
\text { adsorption on soil minerals, } \\
\text { improving models of plant and } \\
\text { microbe carbon dioxide } \\
\text { production, and finding efficient } \\
\text { algorithms for modeling reactive } \\
\text { transport. }\end{array}$ & OU $2-13$ & $08 / 2001$ \\
\hline 17 & Remediation & Inventory & $\begin{array}{l}\text { In-Situ Grouting } \\
\text { Treatability Study }\end{array}$ & $\begin{array}{l}\text { The scope of this study is to } \\
\text { evaluate in situ grouting for } \\
\text { Long Term Disposal and } \\
\text { Containment During Retrieval } \\
\text { options for the Subsurface } \\
\text { Disposal Area at the INEEL. } \\
\text { Field scale testing for in situ } \\
\text { grouting of buried waste will be } \\
\text { completed in FY01. Various } \\
\text { grout mixtures and products will } \\
\text { be evaluated for their use in } \\
\text { treating buried waste at the } \\
\text { Subsurface Disposal Area. }\end{array}$ & $\begin{array}{l}\text { OU 7- } \\
13 / 14\end{array}$ & $09 / 2002$ \\
\hline 23 & Remediation & Inventory & $\begin{array}{l}\text { Attenuation/ } \\
\text { Reactive Barrier } \\
\text { for ICDF }\end{array}$ & $\begin{array}{l}\text { The scope of this study is the } \\
\text { development of a layer within } \\
\text { the ICDF liner system which } \\
\text { will protect the SRPA to } \\
\text { CERCLA requirements from the } \\
\text { inventory planned for disposal in } \\
\text { the ICDF. }\end{array}$ & OU $3-13$ & $09 / 2002$ \\
\hline
\end{tabular}




\begin{tabular}{|c|c|c|c|c|c|c|}
\hline $\begin{array}{l}\text { ID } \\
\text { No. }\end{array}$ & Application & $\begin{array}{l}\text { Research } \\
\text { Area }\end{array}$ & Title & Description & $\begin{array}{l}\text { Product } \\
\text { Provided } \\
\text { To }\end{array}$ & $\begin{array}{l}\text { Desired } \\
\text { Delivery } \\
\text { Date }\end{array}$ \\
\hline 15 & Assessment & Inventory & $\begin{array}{l}\text { Uranium } \\
\text { Solubility Studies }\end{array}$ & $\begin{array}{l}\text { The release mechanisms } \\
\text { associated with uranium will be } \\
\text { examined to determine the } \\
\text { solubility limits of the disposed } \\
\text { chemical waste forms in the } \\
\text { Subsurface Disposal Area at the } \\
\text { INEEL. The results of these } \\
\text { tests will be published and used } \\
\text { in the Baseline Risk Assessment } \\
\text { for OU 7-13/14. }\end{array}$ & $\begin{array}{l}\text { OU 7- } \\
13 / 14\end{array}$ & $09 / 2002$ \\
\hline 22 & Remediation & Inventory & $\begin{array}{l}\text { Tank Contents } \\
\text { Grouting } \\
\text { Treatability Study }\end{array}$ & $\begin{array}{l}\text { This study is to determine } \\
\text { whether the preselected } \\
\text { formulation for solidifying } 55 \\
\text { gallons of sludge in SFE-20 } \\
\text { Tank at the Idaho Nuclear } \\
\text { Technology and Engineering } \\
\text { Center will meet waste } \\
\text { acceptance criteria. The tank } \\
\text { was used to collect hot waste } \\
\text { and contains water and sludge } \\
\text { contaminated radionuclides and } \\
\text { possibly heavy metals and } \\
\text { organic solvents. Solidification } \\
\text { using grout has been selected as } \\
\text { the treatment technology in the } \\
\text { Operable Unit } 3-13 \text { Record of } \\
\text { Decision. This test will only be } \\
\text { performed if the results } \\
\text { analytical tests do not provide } \\
\text { sufficient information to justify } \\
\text { the grout formulation. }\end{array}$ & OU 3-13 & $12 / 2003$ \\
\hline 34 & Remediation & Inventory & $\begin{array}{l}\text { Latest } \\
\text { technologies for } \\
\text { real-time } \\
\text { contaminant } \\
\text { concentration } \\
\text { detection } \\
\end{array}$ & $\begin{array}{l}\text { This is for in-situ measurements } \\
\text { such as gamma radio isotopic } \\
\text { measurements and real time } \\
\text { metal concentration in soils. }\end{array}$ & OU 5-12 & $02 / 2003$ \\
\hline 44 & Assessment & Inventory & $\begin{array}{l}\text { Evaluation of } \\
\text { contaminant } \\
\text { sources } \\
\text { upgradient to } \\
\text { INEEL } \\
\end{array}$ & $\begin{array}{l}\text { This is a site wide } \\
\text { characterization to develop a } \\
\text { basic understanding of flow and } \\
\text { properties of groundwater } \\
\text { upgradient of INEEL. }\end{array}$ & OU 10-8 & $04 / 2003$ \\
\hline 45 & Assessment & Inventory & $\begin{array}{l}\text { Mercury } \\
\text { Treatability Study } \\
\text { at TSF-08 }\end{array}$ & $\begin{array}{l}\text { This study is to develop an } \\
\text { understanding and the potential } \\
\text { for using phytoremediation with } \\
\text { native plants on mercury } \\
\text { contaminated INEEL soils. }\end{array}$ & OU 10-8 & $08 / 2006$ \\
\hline
\end{tabular}




\begin{tabular}{|c|c|c|c|c|c|c|}
\hline $\begin{array}{l}\text { ID } \\
\text { No. }\end{array}$ & Application & $\begin{array}{l}\text { Research } \\
\text { Area }\end{array}$ & Title & Description & $\begin{array}{l}\text { Product } \\
\text { Provided } \\
\text { To } \\
\end{array}$ & $\begin{array}{l}\text { Desired } \\
\text { Delivery } \\
\text { Date }\end{array}$ \\
\hline 26 & $\begin{array}{l}\text { Long Term } \\
\text { Monitoring }\end{array}$ & $\begin{array}{l}\text { Vadose } \\
\text { Zone }\end{array}$ & $\begin{array}{l}\text { Pre-drill detection } \\
\text { of shallow water } \\
\text { flow zones }\end{array}$ & $\begin{array}{l}\text { The study will assess current } \\
\text { capabilities for } \\
\text { characterizing the near-surface } \\
\text { environment using noninvasive } \\
\text { technologies, to identify and } \\
\text { research technology deficiencies, } \\
\text { and to recommend R\&D to fill } \\
\text { these gaps. A long-term view } \\
\text { will be taken that considers new } \\
\text { and improved methods for } \\
\text { relating indirect measurements } \\
\text { to physical, chemical, and } \\
\text { biological properties of the } \\
\text { subsurface. }\end{array}$ & OU $3-13$ & $12 / 2000$ \\
\hline 37 & Assessment & $\begin{array}{l}\text { Vadose } \\
\text { Zone }\end{array}$ & $\begin{array}{l}\text { Evaluation of } \\
\text { Biotic Intrusion } \\
\text { into Waste Caps } \\
\text { and Burial Waste }\end{array}$ & $\begin{array}{l}\text { This research is to develop a } \\
\text { fundamental understanding of } \\
\text { the ecological risk of plants and } \\
\text { animals penetrating caps and } \\
\text { barriers. Results could improve } \\
\text { design and structure integrity. }\end{array}$ & OU 10-4 & $02 / 2001$ \\
\hline 24 & Remediation & $\begin{array}{l}\text { Vadose } \\
\text { Zone }\end{array}$ & $\begin{array}{l}\text { Treatment } \\
\text { Options for } \\
\text { Organically } \\
\text { Contaminated } \\
\text { Wastes }\end{array}$ & $\begin{array}{l}\text { This evaluation and the follow- } \\
\text { on treatability studies will be } \\
\text { performed if treatment for } \\
\text { organically contaminated soils is } \\
\text { required for CERCLA wastes } \\
\text { received at the Staging, Storage, } \\
\text { Sizing, and Treatment Facility } \\
\text { for disposal at ICDF or offsite. } \\
\text { (Current assessments do not } \\
\text { indicate any organic } \\
\text { concentrations above direct } \\
\text { disposal limits. 9/00) }\end{array}$ & OU 3-13 & $09 / 2001$ \\
\hline 33 & Assessment & $\begin{array}{l}\text { Vadose } \\
\text { Zone }\end{array}$ & $\begin{array}{l}\text { Microbe } \\
\text { Characterization }\end{array}$ & $\begin{array}{l}\text { This is to develop methods to } \\
\text { examine the microchemical } \\
\text { environments and surface } \\
\text { interactions of microbes with } \\
\text { mineral surfaces. } \\
\text { Fluorescence spectroscopy, } \\
\text { microspectroscopy, and } \\
\text { conffocal microscopy methods } \\
\text { with appropriate fluorescent } \\
\text { indicators for pH, redox } \\
\text { potential, and metal ions are } \\
\text { being developed. }\end{array}$ & OU 1-7B & $10 / 2002$ \\
\hline 13 & Remediation & $\begin{array}{l}\text { Vadose } \\
\text { Zone }\end{array}$ & $\begin{array}{l}\text { Environmental } \\
\text { Modeling and } \\
\text { Simulation }\end{array}$ & $\begin{array}{l}\text { To develop computational } \\
\text { simulation of mechanical and } \\
\text { chemical systems to improve the } \\
\text { prediction of flow and } \\
\text { contaminant remediation in } \\
\text { subsurface applications, improve } \\
\text { the technologies, processes and } \\
\text { strategies proposed for solution. }\end{array}$ & $\begin{array}{l}\text { OU 3-13 } \\
\text { OU } 10\end{array}$ & $\begin{array}{l}03 / 2002 \\
12 / 2006\end{array}$ \\
\hline
\end{tabular}




\begin{tabular}{|c|c|c|c|c|c|c|}
\hline $\begin{array}{l}\text { ID } \\
\text { No. }\end{array}$ & Application & $\begin{array}{l}\text { Research } \\
\text { Area }\end{array}$ & Title & Description & $\begin{array}{l}\text { Product } \\
\text { Provided } \\
\text { To }\end{array}$ & $\begin{array}{l}\text { Desired } \\
\text { Delivery } \\
\text { Date }\end{array}$ \\
\hline 3 & Assessment & $\begin{array}{l}\text { Vadose } \\
\text { Zone }\end{array}$ & $\begin{array}{l}\text { Chaotic- } \\
\text { Dynamical } \\
\text { Conceptual Model } \\
\text { to Describe Fluid } \\
\text { Flow and } \\
\text { Containment }\end{array}$ & $\begin{array}{l}\text { This study will examine flow } \\
\text { and transport through a fractured } \\
\text { vadose zone as a deterministic } \\
\text { chaotic dynamical process, and } \\
\text { develop a model of it in these } \\
\text { terms. We will first examine } \\
\text { separately the geometric model } \\
\text { of fractured rock and the flow } \\
\text { dynamics model needed to } \\
\text { describe chaotic behavior, then } \\
\text { put the geometry and flow } \\
\text { dynamics together to develop a } \\
\text { chaotic-dynamical model of flow } \\
\text { and transport in a fractured } \\
\text { vadose zone. }\end{array}$ & $\begin{array}{l}\text { OU } 7-10 \\
\& \text { OU } 7-4 \\
\text { OU } 3\end{array}$ & $\begin{array}{l}09 / 2002 \\
03 / 2003\end{array}$ \\
\hline 2 & $\begin{array}{l}\text { Long Term } \\
\text { Monitoring }\end{array}$ & $\begin{array}{l}\text { Vadose } \\
\text { Zone }\end{array}$ & $\begin{array}{l}\text { Control of } \\
\text { Biologically } \\
\text { Active } \\
\text { Degradation } \\
\text { Zones by Vertical } \\
\text { Heterogeneity }\end{array}$ & $\begin{array}{l}\text { The key objective of this } \\
\text { research is to determine the } \\
\text { distribution of biologically } \\
\text { active contaminant } \\
\text { degradation zones in a fractured, } \\
\text { subsurface medium with respect } \\
\text { to vertical heterogeneities. The } \\
\text { fundamental research proposed } \\
\text { will explain the distribution of } \\
\text { microorganisms that can degrade } \\
\text { TCE in the context of the } \\
\text { geochemical and physical } \\
\text { constraints under which these } \\
\text { organisms function. This in turn } \\
\text { will allow better decisions to be } \\
\text { made with regards to the use of } \\
\text { remedial technologies such as } \\
\text { natural attenuation and in situ } \\
\text { bioremediation at this } \\
\text { geologically complex site. }\end{array}$ & OU 1-10 & $03 / 2006$ \\
\hline 4 & $\begin{array}{l}\text { Long Term } \\
\text { Monitoring }\end{array}$ & $\begin{array}{l}\text { Vadose } \\
\text { Zone }\end{array}$ & $\begin{array}{l}\text { Assessment of } \\
\text { Effective } \\
\text { Radioactive } \\
\text { Surface Areas of } \\
\text { Chemically } \\
\text { Heterogeneous } \\
\text { Porous Media }\end{array}$ & $\begin{array}{l}\text { This research will provide a } \\
\text { validated physicochemical } \\
\text { scaling approach to assess the } \\
\text { role of variable reactive surface } \\
\text { area for field-scale contaminant } \\
\text { and bacterial transport. }\end{array}$ & OU 1-10 & $03 / 2006$ \\
\hline 6 & $\begin{array}{l}\text { Long Term } \\
\text { Monitoring }\end{array}$ & $\begin{array}{l}\text { Vadose } \\
\text { Zone }\end{array}$ & $\begin{array}{l}\text { Assessment of In- } \\
\text { situ Intrinsic } \\
\text { Rates of Natural } \\
\text { Attenuation as } \\
\text { Clean-Up }\end{array}$ & $\begin{array}{l}\text { This is to conduct initial proof- } \\
\text { of-principle studies in the } \\
\text { laboratory and to evaluate the } \\
\text { feasibility of a larger field } \\
\text { experiment in the Snake River } \\
\text { Plain Aquifer. }\end{array}$ & OU $1-10$ & $03 / 2006$ \\
\hline
\end{tabular}




\begin{tabular}{|c|c|c|c|c|c|c|}
\hline $\begin{array}{l}\text { ID } \\
\text { No. }\end{array}$ & Application & $\begin{array}{l}\text { Research } \\
\text { Area }\end{array}$ & Title & Description & $\begin{array}{l}\text { Product } \\
\text { Provided } \\
\text { To }\end{array}$ & $\begin{array}{l}\text { Desired } \\
\text { Delivery } \\
\text { Date }\end{array}$ \\
\hline 5 & $\begin{array}{l}\text { Long Term } \\
\text { Monitoring }\end{array}$ & $\begin{array}{l}\text { Vadose } \\
\text { Zone }\end{array}$ & $\begin{array}{l}\text { Evaluation of } \\
\text { SIMS for Direct } \\
\text { Interrogation of } \\
\text { Microbe/Mineral } \\
\text { Interfaces }\end{array}$ & $\begin{array}{l}\text { This is to evaluate static } \\
\text { secondary ion mass spectrometry } \\
\text { (SIMS) as a tool for direct } \\
\text { assessment of microbial } \\
\text { populations at mineral surfaces. } \\
\text { Because SIMS is a sensitive, } \\
\text { surface analysis technique, it has } \\
\text { the potential to directly } \\
\text { interrogate interfacial } \\
\text { interactions between } \\
\text { microorganisms and the mineral } \\
\text { substrate. }\end{array}$ & OU $1-10$ & $03 / 2006$ \\
\hline 9 & $\begin{array}{l}\text { Long Term } \\
\text { Monitoring }\end{array}$ & $\begin{array}{l}\text { Vadose } \\
\text { Zone }\end{array}$ & $\begin{array}{l}\text { Biochemical and } \\
\text { Geochemical } \\
\text { Reactions on } \\
\text { Environmental } \\
\text { Surface }\end{array}$ & $\begin{array}{l}\text { To address direct chemical } \\
\text { interaction of contaminant } \\
\text { species with other chemical } \\
\text { species and mineral surfaces to } \\
\text { improve understanding of how } \\
\text { they affect transport and fate of } \\
\text { contaminants. }\end{array}$ & OU 10 & $09 / 2011$ \\
\hline 10 & $\begin{array}{l}\text { Long Term } \\
\text { Monitoring }\end{array}$ & $\begin{array}{l}\text { Vadose } \\
\text { Zone }\end{array}$ & $\begin{array}{l}\text { Reactive } \\
\text { Transport in } \\
\text { Variably } \\
\text { Saturated Media }\end{array}$ & $\begin{array}{l}\text { To develop a better } \\
\text { understanding of the movement } \\
\text { and transformation of reactive } \\
\text { constituents in heterogeneous, } \\
\text { variably saturated subsurface } \\
\text { media and improve estimates of } \\
\text { fate and mobility of reactive } \\
\text { constituents. }\end{array}$ & OU 10 & $09 / 2011$ \\
\hline 11 & $\begin{array}{l}\text { Long Term } \\
\text { Monitoring }\end{array}$ & $\begin{array}{l}\text { Vadose } \\
\text { Zone } \\
\text { And } \\
\text { Ground- } \\
\text { water }\end{array}$ & $\begin{array}{l}\text { Transport } \\
\text { Phenomena in } \\
\text { Geologic Porous } \\
\text { Media }\end{array}$ & $\begin{array}{l}\text { Multi-year program to } \\
\text { investigate relationships between } \\
\text { bulk-scale biological, chemical, } \\
\text { and physical heterogeneities in } \\
\text { the subsurface to improve } \\
\text { contaminant fate and transport } \\
\text { prediction. }\end{array}$ & OU 10 & $09 / 2011$ \\
\hline 12 & $\begin{array}{l}\text { Long Term } \\
\text { Monitoring }\end{array}$ & $\begin{array}{l}\text { Vadose } \\
\text { Zone } \\
\text { And } \\
\text { Ground- } \\
\text { water }\end{array}$ & $\begin{array}{l}\text { Integrated Sensors } \\
\text { for In-Situ Chem. } \\
\text { Measurement }\end{array}$ & $\begin{array}{l}\text { Addresses detection of low- } \\
\text { energy ions, laser-enhanced IMS } \\
\text { instrumentation, micro array } \\
\text { bisensor, membrane } \\
\text { characterization, and portability. } \\
\text { Addresses characterization and } \\
\text { long-term monitoring needs } \\
\text { related to Stewardship. }\end{array}$ & OU 10 & $09 / 2011$ \\
\hline 30 & $\begin{array}{l}\text { Long Term } \\
\text { Monitoring }\end{array}$ & $\begin{array}{l}\text { Vadose } \\
\text { Zone }\end{array}$ & $\begin{array}{l}\text { Strategies for } \\
\text { Structure and } \\
\text { Reactivity of } \\
\text { Monolayer }\end{array}$ & $\begin{array}{l}\text { To generate methodology and } \\
\text { instrumentation that will provide } \\
\text { direct knowledge of surface- } \\
\text { bound oxyanions with absorbate } \\
\text { molecules. Improve predictive } \\
\text { capability at meso and macro- } \\
\text { scales. }\end{array}$ & OU10 & $09 / 2011$ \\
\hline
\end{tabular}




\begin{tabular}{|c|c|c|c|c|c|c|}
\hline $\begin{array}{l}\text { ID } \\
\text { No. }\end{array}$ & Application & $\begin{array}{l}\text { Research } \\
\text { Area }\end{array}$ & Title & Description & $\begin{array}{l}\text { Product } \\
\text { Provided } \\
\text { To }\end{array}$ & $\begin{array}{l}\text { Desired } \\
\text { Delivery } \\
\text { Date }\end{array}$ \\
\hline 35 & Assessment & $\begin{array}{l}\text { Ground- } \\
\text { water }\end{array}$ & $\begin{array}{l}\text { Evaluation of } \\
\text { Hyperspectural } \\
\text { Imaging to } \\
\text { support } \\
\text { contaminant } \\
\text { Plume } \\
\text { Identification }\end{array}$ & $\begin{array}{l}\text { To develop a sensor to detect } \\
\text { trace amounts of volatile organic } \\
\text { compounds in the plume of in- } \\
\text { situ vitrification for remediating } \\
\text { buried mixed waste. }\end{array}$ & OU 10 & $03 / 2001$ \\
\hline 43 & Assessment & $\begin{array}{l}\text { Ground- } \\
\text { water }\end{array}$ & $\begin{array}{l}\text { Regional } \\
\text { Groundwater fate } \\
\text { and transport } \\
\text { Model } \\
\text { Development }\end{array}$ & $\begin{array}{l}\text { To develop a Regional } \\
\text { Groundwater Model which } \\
\text { incorporates all the individual } \\
\text { WAG Groundwater Models } \\
\text { across the INEEL site to } \\
\text { understand the interaction (or } \\
\text { lack of interaction) between } \\
\text { individual WAG Plumes. }\end{array}$ & OU 10 & $10 / 2002$ \\
\hline 8 & Assessment & $\begin{array}{l}\text { Ground- } \\
\text { water }\end{array}$ & $\begin{array}{l}\text { Isobaric } \\
\text { Groundwater Well } \\
\text { Design and } \\
\text { Implementation }\end{array}$ & $\begin{array}{l}\text { This project will research, } \\
\text { design, build, and test an } \\
\text { "isobaric" groundwater well for } \\
\text { obtaining accurate aquifer water } \\
\text { levels. The aim of this research } \\
\text { is to prove the practicability of } \\
\text { the technique by testing the } \\
\text { devices on multiple wells in } \\
\text { varying geologic media. }\end{array}$ & OU 10 & $09 / 2002$ \\
\hline 31 & Assessment & $\begin{array}{l}\text { Ground- } \\
\text { water }\end{array}$ & $\begin{array}{l}\text { Treatability } \\
\text { Studies for Barrier } \\
\text { and Encapsulation } \\
\text { Material to } \\
\text { Prevent } \\
\text { Contaminant } \\
\text { Transport to the } \\
\text { SRPA }\end{array}$ & $\begin{array}{l}\text { This project will involve testing } \\
\text { of rad stable polymers that will } \\
\text { yield hydraulic conductivity of } \\
10^{\wedge}-7 \text { to } 10^{\wedge}-8 \mathrm{~cm} / \mathrm{sec} \text { in order } \\
\text { to "lock" up mobile radionuclide } \\
\text { species within the Tank Farm } \\
\text { soils. }\end{array}$ & OU 3-14 & $12 / 2004$ \\
\hline 21 & $\begin{array}{l}\text { Long Term } \\
\text { Monitoring }\end{array}$ & $\begin{array}{l}\text { Ground- } \\
\text { water }\end{array}$ & $\begin{array}{l}\text { Evaluation of } \\
\text { Groundwater } \\
\text { Model } \\
\text { Assumptions }\end{array}$ & $\begin{array}{l}\text { This project will develop the } \\
\text { ability to represent the important } \\
\text { physical, biological, and } \\
\text { geochemical processes and } \\
\text { properties of vadose zone soils } \\
\text { and sediments in a modeling } \\
\text { framework that allows the } \\
\text { transport, retention, and } \\
\text { transformation of contaminants } \\
\text { and other solutes to be } \\
\text { accurately assessed. }\end{array}$ & OU 10 & $09 / 2011$ \\
\hline
\end{tabular}

